\title{
Clio
}

Women, Gender, History

$40 \mid 2014$

Making Gender with Things

\section{Benoîte Cadeau-Fessel and the birth of midwifery in nineteenth-century Peru}

Benoîte Cadeau-Fessel et la naissance de la profession de sage-femme. Pérou, XIX siècle

\section{Lissell Quiroz-Perez}

Translator. Heloise Finch-Boyer

\section{Q OpenEdition}

\section{Journals}

Electronic version

URL: http://journals.openedition.org/cliowgh/727

DOI: 10.4000/cliowgh.727

ISSN: 2554-3822

Publisher

Belin

\section{Electronic reference}

Lissell Quiroz-Perez, "Benoîte Cadeau-Fessel and the birth of midwifery in nineteenth-century Peru », Clio [Online], 40 | 2014, Online since 15 April 2015, connection on 20 April 2019. URL : http:// journals.openedition.org/cliowgh/727 ; DOI : 10.4000/cliowgh.727 


\title{
Benoîte Cadeau-Fessel and the birth of midwifery in nineteenth-century Peru
}

\author{
Lissell QUIROZ-PEREZ
}

The history of Latin American motherhood has yet to be told. ${ }^{1}$ Despite a growing interest in Latin American women's history, the subject of childbirth has attracted little attention from historians. In the 1980s, Françoise Thébaud noted that the history of motherhood in general had barely been prospected, and for Latin America this statement still holds true today. ${ }^{2}$ Nonetheless, childbirth and labour have a history, as scholars such as Jacques Gélis or Yvonne Knibiehler have demonstrated. ${ }^{3}$

The nineteenth century is a key moment for understanding the history of motherhood in the Spanish-speaking world. Until the end of the eighteenth century, childbirth occurred in an almost entirely feminine sphere because Hispanic obstetrics had not experienced the same growth as elsewhere, France and Britain for example. In general, doctors lacked expertise in the subject. Furthermore, the presence of men amongst women in labour was discouraged by a sense of female modesty, in a social context strongly influenced by Roman Catholicism.

This situation was even more striking in Latin America where European medicine was always imported with a few years' delay. ${ }^{4} \mathrm{New}$

1 Since the end of the 1990s, Latin American women's history has been a vibrant regional research field, as demonstrated by the following recent publications: Garrido González 1997; Andreo García 2002; Morant Deusa 2005-2008.

2 Thébaud 2004: 58.

3 Gélis 1984, 1988; Knibiehler 1980, 2007; Thébaud 2005.

4 This article deals with the history of urban Peruvian motherhood, a subject for which sources are available. For nineteeth-century indigenous Peruvian society, 
ways of thinking about birth emerged in the second half of the eighteenth century, during the period of the Hispanic Enlightenment and the Bourbon reforms. The medical profession gained in status and at the same time the monarchy decided to control the profession of midwives. In 1750 the Spanish Crown ordained that women practising midwifery be examined by the Royal Medical Board (Protomedicato) and ordered professors to write instruction booklets for them. ${ }^{5}$ There was not enough time for these orders to be applied to the American Viceroyalties. Political upheaval there only ended with the birth of independent Latin American states and their separation from Spain.

In Peru, men of the Enlightenment came to power in the 1820 s with a strong interest in medicine. They believed they were faced with a critical demographic problem. In 1836, Peru had nearly 1.4 million inhabitants in an enormous country that was even larger than contemporary Peru. ${ }^{6}$ The spectre of [European] "depopulation" in Peru became a subject that obsessed the elites in power throughout the nineteenth century. ${ }^{7}$ This is why motherhood became a key interest for them, while at the same time the practices of the women attending to childbirth came under ever-closer scrutiny. In a century defined by the development of medicine and by hygienist thought, traditional birth assistants were maligned, criticized as ignorant, dirty and coarse. This allowed the figure of the midwife to emerge in many countries. A midwife was an educated woman, with an elementary knowledge of obstetrics, who nevertheless remained subordinate to an all-knowing

there is an unfortunate lack of written documentation. In the Peruvian Andes and Amazonian regions, separation of the sexes during childbirth appears to have been less rigid. This is perhaps because of the importance of traditional (male) healers and shamans in some areas, which continues to the present day, but we do not have written sources allowing us to confirm this. In urban areas, especially Lima, the sources only refer to matronas and female healers.

5 Lanning 1985: 95.

6 Basadre 1963: 513.

7 The issue of depopulation appears in many nineteenth-century states, including France. For a new state such as Peru this problem appeared more pressing. At this time, France had more than 30 million inhabitants, Spain over 11 million and Mexico almost 8 million. 
doctor who directed the action and had the final say. ${ }^{8}$ These midwives principally worked in maternity hospitals that served both as training schools and as their workplace. How and when did this major change in the history of obstetrics and birth happen? The study of the Peruvian case provides an interesting perspective to this question.

The history of Lima's maternity hospital is unusual in a number of ways. It was founded in 1826, when Peru created its first republican institutions after the long years of the Wars of Independence. ${ }^{9}$ It was the first Latin American hospital to combine clinical training with a school of midwifery, mirroring the French model at the Port Royal Maternity Hospital in Paris. Mexico, in contrast, did not have a Casa de Maternidad until the 1860s, largely on the initiative of the Empress Carlota, wife of Maximilian I. ${ }^{10}$ And in Buenos Aires, hospitals did not reserve wards for pregnant women and delivery until the 1890s. ${ }^{11}$ The chief reason for Peru's early creation of a maternity hospital was the presence of an unusual midwife. Benoite Cadeau-Fessel, also known as "Madame Fessel" greatly contributed to the history of Peruvian obstetrics from her arrival in Lima in 1826.

A number of historical sources allow us to understand how this occurred. While little is known about her husband, a doctor, Benoite Cadeau-Fessel wrote a great deal during her expatriate years in Latin America. ${ }^{12}$ She was an energetic and tireless woman who left a number of writings, from manuals for students and pregnant women to detailed clinical notes. Additionally, the Peruvian National Archives also hold administrative documents about the maternity hospital of Lima. ${ }^{13}$

8 This has been studied mostly in the Hispanic case: Ortiz Gómez 1992; Carrillo 1999; Diaz Robles and Oropeza Sandoval 2007; Restrepo 2006; Zárate 2007; Quiroz-Pérez 2012.

9 The armies of General San Martín liberated Peru in 1821. But the Royalists maintained a loyalist stronghold and war continued until December 1824, when the Republic was finally created.

10 Morales Suárez 2009: 271-277.

11 Nari 2004: 121-122.

12 Cadeau-Fessel 1825, 1827a, 1827b, 1830a and 1830b.

13 These archives chiefly contain administrative correspondence from the Ministry of Justice, Welfare and Education relative to the founding of the maternity hospital in Lima. 
Studying the foundation of Lima's maternity hospital offers new angles on the history of social attitudes, the history of the state and the history of medicine. Firstly it provides a new perspective on changing Peruvian social attitudes about birth. From being understood as a purely private event, birth increasingly became a subject of public debate as doctors progressively became more interested in the perinatal period. In this context, midwives such as Benoite Cadeau-Fessel increasingly deployed a scientific and medical discourse in order to legitimize their authority and take a central role in pregnancy and childbirth.

The nineteenth century was a key moment in this redistribution of responsibilities. Peruvian midwives were able to uphold their important role in the medical profession by adopting medical precepts and creating a qualified profession that was recognized by educated Peruvian society. In contrast, midwives in Peru's major northern neighbour, the United States, were kept away from maternity hospitals to the benefit of doctors. ${ }^{14}$

Paying attention to the origins of the Lima maternity hospital also offers important perspectives on the history of medicine which, alongside the combat against epidemics, was also overturning previous practices in obstetrics and making possible the creation of new disciplines such as gynaecology and paediatrics. In a broader sense, studying this hospital also helps us to understand the history of the Peruvian state. The Lima maternity hospital was at the heart of nineteenth-century Latin American political, social and cultural history, through its place as a charitable institution, midwifery school and a place of experimental public health policy. In this whirlwind time of experiment and reform, Benoite Cadeau-Fessel's trajectory enables us to understand the stakes of this new "way of experiencing the world". ${ }^{15}$

\section{A "Madame Lachapelle" in Peru}

Benoîte Cadeau-Fessel was born Benoîte Pauline Cadeau in Lyons in 1792. She studied midwifery at the Port Royal Maternity Hospital in

\footnotetext{
14 Walzer Leavitt 1986.

15 Gélis 1988: 490.
} 
Paris, which opened in 1802. This provided high-quality training that combined theoretical and practical elements. ${ }^{16}$ Her apprenticeship took place at the Faculty of Medicine in Paris between 1 July 1816 and 30 June $1818 .{ }^{17}$ As a qualified first-class midwife, she was certified to practise all over France, as opposed to second-class midwives who were trained only for departmental [i.e. regional] hospitals. ${ }^{18}$ As Scarlett Beauvalet-Boutouyrie has noted, midwives were very conscious of the fact that they were an elite group created through their rigorous selection and training programme, and Benoite Cadeau was especially aware of this. Wherever she went, she brandished her Paris maternity hospital diploma as well as the various prizes she had obtained during her training, such as the medal in obstetrics, the first prize for observing the different characteristics of vaccination, and the first prize for botany. ${ }^{19}$ The Maternity Training Hospital had set up these prizes to test the knowledge of the students and to encourage competition between them. Prizewinners could be sure of respect from their peers and from their superiors - chief midwives and chief doctors. Benoite Cadeau was destined to have a very good career, particularly because she had been the pupil of a very active chief midwife, Marie-Louise Lachapelle (1769-1821). Lachapelle had played an important role in the organization and the reputation of the school, becoming famous for the quality of her teaching, her competence and the devotion and moral comfort that she gave to women in her care. ${ }^{20}$ Benoite Cadeau seems to have deeply admired Lachapelle, presenting herself as being from the "Lachapelle school" and frequently citing her work. ${ }^{21}$

\footnotetext{
16 Beauvalet-Boutouyrie 1999.

17 Cadeau-Fessel 1825: II.

18 Beauvalet-Boutouyrie 1999: 112.

19 Cadeau-Fessel 1825: I.

20 Beauvalet-Boutouyrie 1999: 127.

21 Her work Consejos a las mujeres encinta (Cadeau-Fessel 1825) ends with a homage to Marie-Louise Lachapelle: "I cannot stop the tears of sadness and gratitude flowing when I think back to this dignified woman, who particularly shaped my studies in the art of obstetrics. She was a model of charity, and her modesty was only matched by her scientific skill."
} 
The post of chief midwife at the Paris Maternity Hospital was, however, difficult to obtain. Perhaps Benoite Cadeau aspired to take the place of her mentor, but Marie-Louise Lachapelle had already chosen as her successor Clémentine Hucherard, another pupil from Benoite Cadeau's graduating class. ${ }^{22}$ At that time numerous Europeans were attracted to the New World because of the possibilities offered by the newly independent states. Benoite Cadeau therefore left for New Orleans in 1823 with her husband Jean-Baptiste Fessel, a doctor and public health officer. Presumably they chose New Orleans because of its cultural proximity to France and for the contacts that French doctors had with the city. Madame Fessel brought three letters of recommendation with her, written by Antoine Dubois (Professor at the Paris Faculty of Medicine). One was addressed to Alexandre Labranche, another to his son Octave, who was president of the Louisiana House of Representatives. She also had a fulsome letter written by Dubois to the doctor who was secretary for the Societe Medicale de la Nowvelle-Orléans, [the Creole French medical association]. ${ }^{23}$ The couple intended to found a maternity hospital in New Orleans following the Paris model. However Madame Fessel's hopes were quickly dashed. As she later recounted, the climate did not suit her. It is also probable that she did not receive the welcome upon which she had counted. She and her husband then travelled south and set up home in Guadalajara (a town in north-west Mexico). On 16 December 1824 she applied to its Cabildo (municipal government) for permission to create a midwifery school. This proves not only that she hoped to continue her own private practice, but also that she hoped to become chief midwife of a maternity hospital just like Paris. Her local representative, town councillor (regidor) Juan de Dios Cañedo offered to support the project, but it was not accepted. ${ }^{24}$ Nevertheless Benoite Cadeau-Fessel had enough time to write a small booklet entitled Advice for Pregnant Women

22 Beauvalet-Boutouyrie 1999: 129.

23 Cadeau-Fessel 1825. Translator's note: English-speaking physicians in New Orleans joined the Physico-medical society, French-speaking ones joined the Société Médicale de la Nouvelle-Orléans see Matas, Rudolph, and John Duffy. 1958. History of medicine in Louisiana. [n.p.]: The Rudolph Matas Trust Fund.

24 Cárdenas Castillo 2010. 
(Consejos a las mujeres encintas), which was translated into Spanish and published at Guadalajara. Despite her enthusiasm for her hospital project, and the energy she had spent promoting it, the Fessel couple had to resign themselves to leaving Mexico.

It is unclear why they chose Peru as their next destination. Nonetheless, by 1826 they were in Lima. Benoite Cadeau-Fessel arrived in the town at exactly the right time. With Peru's Wars of Independence finally over, Limeño public authorities could finally create new republican institutions. At that time, the minister of finances was Hipólito Unanue, the most important Peruvian doctor of the era and Simon Bolívar's personal physician. Unanue had made his name spearheading the fight against unqualified birth attendants [matrones] and for his interest in combating childhood diseases. ${ }^{25}$

As soon as Benoite Cadeau-Fessel and her husband arrived in Lima, they presented their diplomas and academic references to the Medical College Protomedicato General de la Repuiblica, which regulated health professionals. ${ }^{26}$ The general secretary of this College was Miguel Tafur y Zea (1766-1833), a medical doctor, Vice Chancellor of the University of Lima and a personal friend and colleague of Hipólito Unanue. Thanks to the influence of these two men, Benoite Cadeau-Fessel's application was accepted. Additionally, she obtained the support of the Peruvian state ordaining the establishment of the Lima maternity hospital. ${ }^{27}$ Without further ado, the Fessels set themselves up in the building of an ex-military hospital and waited for the Peruvian government to equip the maternity hospital and officially inaugurate it. ${ }^{28}$

25 Hipólito Unanue had published numerous articles on this subject in Mercurio Peruano (1790-1795) as well as in his 1806 Observations on the Climate of Lima (Observaciones sobre el clima de Lima).

26 Protomedicato General de la República emerged from the defunct Real Tribunal du Protomedicato which had been created in Spain in the fifteenth century and applied to the colonies. In Latin America, only the two capitals of the oldest Viceroyalties, Mexico and Lima, had obtained the right to create this type of organisation, which endured in Peru until the middle of the nineteenth century.

27 Decree of 10 October 1826 available in Archivo digital de la legislación en el Perú (www.congreso.gob.pe, accessed 15/04/11).

28 "Expediente de Mme Benita Paulina Cadeau de Fessel seguido en 1836 sobre la venta de sus bienes y libros, antes de marcharse a Francia” in Rabí Chara 2004: 38. 
Benoite Cadeau-Fessel was more active and entrepreneurial than her husband. Despite her own admission that she did not speak Spanish fluently, she unhesitatingly wrote numerous pamphlets. As soon as she obtained permission from the College of Medicine to practise as a midwife, she published a leaflet announcing the introduction of an obstetrics course. ${ }^{29}$ She frequently sent articles to the main newspapers in Lima to explain her actions and defend her profession. Outside her own work, she found the time to write obstetrics manuals, publishing five in ten years. ${ }^{30}$ Her husband appears to have worked with her and acted as guarantor for her activities.

Madame Fessel nevertheless had to wait nearly three years to finally see the creation of the Maternity Hospital (Casa de Maternidad). In May 1830 the couple finally left the clinic for a building adjoining the Women's Hospital (Hospital de la Caridad). As director, Benoite Cadeau-Fessel was granted 1,000 pesos to equip the building. The government also gave the hospital an annual budget of 3,600 pesos divided in three equal parts. ${ }^{31}$ The first third was intended for the upkeep of the building, the second third for student scholarships and the third corresponded to the annual salary of the director. ${ }^{32}$ Additionally, the Peruvian government allocated the maternity hospital a bonus of 4,000 pesos. While this sum was smaller than they had hoped, the Fessel couple took over the direction of the maternity hospital and organised it as they wished with Benoite Cadeau-Fessel as the director and her husband as the chief doctor. ${ }^{33}$

29 Cadeau-Fessel 1826.

30 Cadeau-Fessel 1826.

31 Rabí Chara 2004: 45.

32 In comparison, the annual salary of a minister was 5,500 pesos, a magistrate 4,000 pesos, a clerk in a ministry 1,000 pesos and a concierge 400 pesos. In Reflexión sobre la organización de la Maternidad o Escuela de Partos en Lima (CadeauFessel 1827: 101), Cadeau-Fessel compared the salary of the chief midwife of the maternity hospital in Paris with her own, far smaller, salary.

33 Carrasco 1826. 


\section{Theoretical training and innovative practice in the Latin American world}

The Lima maternity hospital was now able to take in student midwives, with board and lodging. At that time Lima had far fewer candidates than in Paris, where there had been 60 per graduating class. The eight scholarships disbursed by the Peruvian government were therefore sufficient to cover student needs. The first graduating class of five midwives was officially sworn in in front of the Protomedicato in $1833 .{ }^{34}$

These women had benefited from high quality training, which clearly distinguished them from other practitioners. Until then, untrained midwives [matronas] had assisted women in labour, calling on doctors and surgeons for difficult cases. These two groups of people were distinct, which somewhat limited their efficacity. The untrained matronas were often close to expectant mothers, but lacked precise theoretical knowledge, especially in anatomy. Conversely, doctors and surgeons could not always put their theoretical knowledge into practice because women in childbirth did not trust them and were willing to call on their services only in extreme emergencies.

Benoite Cadeau-Fessel intended to bridge this gap. On one hand she was at pains to distinguish qualified midwives from unqualified matronas, whom she regarded with "pity because, lacking instruction, they are absolutely incapable of shortening suffering or the length of labour, or of knowing how and when the innocent creatures will be born who risk perishing between their hands [...]." 35 In her writing, Benoite Cadeau-Fessel intended to demonstrate the empirical, superstitious even, practices of these [unqualified] handywomen or recibidoras (receivers).

In one example, she describes the case of woman suffering from placenta retention 24 hours after the second stage of her labour. The matrona had attempted to expel the placenta by giving the woman enemas and by using fumigation. When these remedies proved fruitless, this matrona put a black hat on the woman in labour and

\footnotetext{
34 Rabí Chara 2004: 49.

35 Cadeau-Fessel 1830b: V.
} 
asked her to blow into a tube, a remedy said to be effective in the case of placenta retention. ${ }^{36}$

Nevertheless, Benoite Cadeau-Fessel did not entirely trust the theoretical knowledge of doctors either, a stance all the more remarkable since her own husband was the chief doctor of the Lima maternity hospital. When Cadeau-Fessel assisted women in labour, she proudly asserted her expertise on the subject, being aware that Peruvian doctors had very little knowledge of obstetrics because of their lack of clinical experience.

Without wishing to criticize or diminish the merits of the people who practise the honourable medical profession in Lima, it would be easy to prove that this city does not have obstetricians [accoucheurs] with the factual knowledge required by the medical profession. Unless, that is, we suppose that doubt, temerity or even chance can ever replace the wise and indispensable precepts of theory applied to sound practice. ${ }^{37}$

But Cadeau-Fessel did not stop there. She strongly believed that doctors should not have control over births despite their scientific knowledge and she clearly expressed this point. Her Advice to Pregnant Women (Consejos a las mujeres encintas) written in 1825, opens with a quotation from the work of Philippe Hecquet entitled De l'Indécence aux hommes d'accoucher les femmes (1707) [On the indecency of having men conduct childbirth]. In her conclusion, she borrows a quotation from the work of famous doctor Pierre Roussel's Le Système physique et moral de la femme. [The physical and moral system of woman]

Although the act of giving birth is part of the art of healing, it is not meant to be practised by men. The nature of this act, the modest amount of knowledge it requires, the complete and absolute confidence which people of the same sex should naturally have for each other; finally everything cries out for women: this work seems to be their own; they have all the necessary advantages to do it successfully. ${ }^{38}$

Madame Fessel thus considered that childbirth should remain in the feminine sphere, with midwives given the most important role. All of her work demonstrates this desire to elevate midwifery to the

\footnotetext{
36 Cadeau-Fessel 1830b: 5.

37 Cadeau-Fessel 1830b: V.

38 Roussel 1803: 217.
} 
level of an art, i.e. a profession demanding aptitude, technical skills and specific knowledge.

This is why Benoite Cadeau-Fessel is one of a long line of midwives who made important contributions to the progress of obstetrical science. These include Louise Bourgeois (1563-1636), midwife to Marie de Médicis, Marguerite du Tertre de la Marche (1638-1706), chief midwife of the Hôtel-Dieu, Angélique Marguerite le Boursier du Coudray (1712-1789), first woman to use models in her birthing lectures, Marie-Jonet Dugés (1730-1797), Marie-Louise Lachapelle (1769-1821) and Marie-Anne Victorine Boivin (17731847), all chief midwives of Parisian hospitals. Beyond Benoite Cadeau-Fessel, many European midwives were directly influenced by these historic figures, as other historians have demonstrated. ${ }^{39}$

Following the example of these historic midwives, Benoite Cadeau-Fessel wished to train specialists in the art of giving birth who broke with traditional ways of bringing children into the world. Benoite Cadeau-Fessel and her followers began by introducing the feminine term obstetriz (a neologism derived from the Latin obstetrix) into Spanish. ${ }^{40}$ This self-description was not an academic one, and demonstrates Benoite Cadeau-Fessel's wish to underscore the scientific legitimacy of midwifery.

It must be said that the art of childbirth can only be learnt in a school. In fact, in order to save a mother and her child it is indispensable to have witnessed practical demonstrations both of the different positions of the foetus as well as the necessary instruments for induced births [accouchements contre nature] and prolonged labour. It is impossible to get experience in handling them without the use of a model and the study of anatomy, in order to learn the necessary manipulations. ${ }^{41}$

The young women who entered the Lima Maternity School had already undertaken prior training either in school or with home tutors, something which was not available to all Peruvian women in the nineteenth century. Furthermore, candidates for the School had to prove both their intellectual and moral qualities, far beyond

\footnotetext{
39 Ortiz Gómez 1992; Marland 1993; Rattner Gelbart 1998.

40 The use of this term remains in the Peruvian lexicon and the word obstetriz is now considered as a distinctive regional word in contemporary Latin American Spanish.

41 Cadeau-Fessel 1827a: "Prólogo".
} 
requirements for men who wanted to enter the faculty of medicine. For all these reasons, the student midwives were principally from the petite-bourgeoisie of Peru. In addition to this set of socio-economic factors, was the issue of ethnic origins: Peruvian obstetrices were white or mestizas, in contrast with the unqualified matronas, the vast majority of whom were Indian, black or mulata. The social distinction of the midwife was also based on these differences, especially given the social and ethnic divisions at the heart of highly stratified nineteenth-century Peruvian society.

Just like in Paris, anatomical knowledge was at the heart of the Peruvian midwifery course. The curriculum for midwifery students was similar to the obstetrics course for male medical students at the faculty of medicine in Lima, although the women studied in four years what the men undertook in one year. ${ }^{42}$ Both sets of students studied natural and complicated deliveries, as well as diseases of women in labour and of new-born babies. Benoite Cadeau-Fessel required her students to be fluent in French in order to be able to read the work of the great obstetricians who, for the most part, had written in French. ${ }^{43}$

For this reason, the library of the maternity hospital of Lima contained works by Claude-Martin Gardien (Traité des Accouchements, des maladies des femmes, de l'éducation médicinale et des maladies propres à cet âge, Paris, 1807, 4 vols), ${ }^{44}$ Jean-Louis Baudelocque (Principes sur l'art des accouchements, par demandes et réponses, en faveur des élèves sages-femmes, $4^{\text {th }} \mathrm{ed}$., Paris, 1812), ${ }^{45}$ Joseph Capuron (Cours théorique et pratique des accouchements, Paris, 1811; and Traité des maladies des femmes, depuis la puberté

42 This is another specific feature of midwifery training in Peru. Elsewhere, from Madrid to Mexico, midwifery training takes two or three years, as opposed to four in Peru.

43 This was not an unreasonable expectation at the time. Peruvian elites were steeped in the French language. Politicians, legal scholars and even doctors were almost all bilingual. The important development of French and English language learning in the $19^{\text {th }}$ century happened to the detriment of Latin, which had been the language of learning in the colonial period. See Lissell Quiroz-Pérez 1996.

44 Treatise on Giving Birth, female diseases, medical education, medicinal education and diseases pertinent to this age.

45 Principles on the art of giving birth, in question and answer form, for student midwives. 
jusqu'à l'âge critique inclusivement, Paris, 1812). ${ }^{46}$ In addition to these works were older studies such as those by André Levret (L'Art des accouchemens, démontré par des principes de physique et de méchanique, pour servir d'introduction et de base à des leçons particulières, 3rd ed., Paris, 1766;47 and Observations sur les causes et les accidens de plusieurs accouchemens laborieux. Suite des Observations..., Paris, 1780). ${ }^{48}$ There were also a few works by nonFrench authors in the library such as William Smellie's Observations sur les accouchements, ou Suite de la théorie et pratique de cet art, Paris, 177749 and Johann Georg Roederer's De Axi Pelvis Programma quo... Ad orationem benevole audientiam invitat, et simul lectiones suas denuo indicit, Göttingen, 1751. In addition, the library contained manuals written by midwives such as Marie-Louise Lachapelle's Pratique des accouchemens ou Mémoires et observations choisies sur les points les plus importans de l'art, Paris, $1821^{50}$ as well as Benoite Cadeau-Fessel's own works translated into Spanish ${ }^{51}$ (Consejos a las mujeres encinta, Guadalajara, 1825; Curso elemental de partos, Lima, 1827 and Práctica de partos, Lima, 1830). ${ }^{52}$

The teaching method combined both traditional and more innovative approaches. It firstly required both rote learning and repetition. Student midwives had to memorize the answers to questions presented in the lectures, with the goal of creating reflex responses. Repetition was part of a broader system of reciprocal teaching, where advanced students taught inexperienced ones, following the model of the Port Royal Maternity Hospital in Paris. ${ }^{53}$ In addition to these often tedious and abstract memorization exercises, Benoite Cadeau-Fessel did, however, provide practical training. She used mannequins and illustrative engravings that she had brought from France for this

46 Theoretical and practical course on labour and Treatise on the diseases of women, inclusively from puberty to the critical age.

47 The art of giving birth as demonstrated through physical and mechanical principles, serving as an introduction and foundation for private lessons.

48 Observations on the causes and accidents of numerous difficult deliveries, with additional comments.

49 Observations of deliveries and further remarks on the theory and practice of this art.

50 The practice of deliveries or theses and choice observations on the most important points of the art.

51 Advice to pregnant women, Elementary course in delivery and The practice of delivery.

52 Archivo de la Beneficencia de Lima 1836.

53 Beauvalet-Boutouyrie 1999: 163. 
purpose, even displaying foetuses preserved in wine to her students. ${ }^{54}$ As chief doctor and chief midwife, Cadeau-Fessel and her husband gave lectures in the main lecture hall of the School of Medicine. Its theoretical curriculum strongly distinguished student midwives from the rest of Lima's female population. They were the first women to follow classes at university and to mix with medical students. This boundary crossing sometimes gave rise to suspicion and jealousy by certain medical professionals who attempted to belittle midwife students by criticising their lack of culture and learning. ${ }^{55}$ Their mistrust was also because qualified midwives had clinical experience that surpassed even the greatest doctors of the age. During their fouryear training, the student midwives were present at between 40 and 100 births. Final year medical students would have seen 10 cases at most. In addition to this extensive practical experience there was also a particular attitude towards women in labour.

\section{Accompanying and assisting women in labour}

Unlike doctors or even obstetrics specialists, Benoite Cadeau-Fessel did not see women as guinea pigs to be experimented upon. Neither was her agenda particularly aimed at increasing the Peruvian birth rate. From her adolescence, Cadeau-Fessel claimed to have been motivated by the "desire to diminish the bad things which, alas are associated with the respectable word mother." 56 Faithfully following the example of Marie-Louise Lachapelle, Benoite Cadeau-Fessel believed that the midwife should never judge the mother in labour, whether she was Indian, black, white, rich, poor, married or single: on the contrary she should sympathize with her. In her study of 45 clinical cases, it is the profound respect that Cadeau-Fessel demonstrates for the distressed women she faces that comes out most strongly. As soon as she arrived at the bedside of the desperate

\footnotetext{
54 Archivo de la Beneficencia de Lima 1836.

55 These criticisms were disseminated in the medical press in articles about the Lima Maternity Hospital.

56 Cadeau-Fessel 1826.
} 
women who had been suffering for hours, days even, she hastened to calm them down and give them moral support.

Above all, Benoîte Cadeau-Fessel fought against practices from another era aiming to speed up labour. She criticised them because matronas could inadvertently make manipulations with irreparable consequences. She stated in one of her books:

In my Curso elemental de partos intended for the use of student midwives in Lima, I have already referred to the supposed magical virtues of the black hat and the tube in the case of placenta retention. Enlightened people in this capital city consider all of these reprehensible idiocies as worthy of compassion. But there are other customs which need the most attentive vigilance of the police, because they tend to do no more or less than forever ruin the life of the patient by cutting the perineum with fingernails or with a piece of glass. Whereas, one of the most important foundational principles of the art of labour, at the moment where the head emerges, is to firmly support the perineum with the most careful attention in order to avoid the splitting of this zone which never heals. ${ }^{57}$

Unfortunately, as Benoite Cadeau-Fessel often complained, qualified midwives were only called once the labour became complicated. She blamed this situation on the recibidoras' lack of medical knowledge. One of her examples was a very young domestic worker who had called a "matron" to help her give birth. After 12 hours of labour and intense pain, the latter called "two strong black men" to shake the woman, which she believed would help the baby to emerge. Imagine her surprise when she perceived a tumour, the size of a baby's head, coming out of the vulva. The "matron" fearful of what she thought was a monster, quickly ran away leaving the young woman helpless with her pain and fear. It was at that moment that Benoite Cadeau-Fessel arrived. After palpation she discovered that the "tumour" was nothing more than a protuberance formed by the amniotic sac. ${ }^{58}$

A faithful student of Baudelocque and Marie-Louise Lachapelle, Benoite Cadeau-Fessel believed that observation was of utmost importance. Because giving birth was a natural function, she considered that nature had to be allowed to follow its course as much

57 Cadeau-Fessel 1830b: 5.

58 Cadeau-Fessel 1830b: 43-44. 
as possible. In all the encounters that she describes, the midwife begins by enquiring about the health of the woman in labour before systematically proceeding to the vaginal examination to understand the patient's state. Reading these observations, it appears that Benoite Cadeau-Fessel was completely competent and undeniably possessed savoir-faire. Her gestures appear sure and precise. Thanks to her observations and palpation she rapidly diagnoses the problem causing pain to the woman in labour. Her main weakness derived from the available treatment for pain, fever and haemorrhage. Existing remedies, which had evolved little since the seventeenth century, centred around bleeding, enemas and plant-based pharmacopoeia. ${ }^{59}$ Yet doctors in the same period had little better to offer, and Benoite Cadeau-Fessel was simply dependent on the medicine of her era.

Observation did not mean waiting too long before intervening. Countering the opinion of a large number of Peruvian doctors, she opposed the "waiting method" and fought to push the "active medicine" approach, which supported surgical intervention if necessary. Madame Fessel supported this point of view by drawing on scientific references, in the same way that a doctor would have done. Blessed with a strong character, she was neither intimidated by the presence of eminent doctors at the bedside of women in labour, nor was she bothered by better off social groups.

One of her interventions, for example, occurred with Señora Castañeda, a woman from a well-off family who presented a breech birth. The family, and the doctor called in to help refused to intervene, even though Benoite Cadeau-Fessel recommended manipulating the foetus with the help of her hand, to make its delivery easier.

More than once I said to these men that if they stopped me from taking advantage of a few opportune moments, it would no longer be possible to do this manipulation. They all stubbornly attempted to delay it. At midday I demanded a consultation and the doctors (who only ever met at 5 o'clock in the evening) said that it would have to wait until 9 o'clock. But, during this long stretch of time the woman in labour was overcome by convulsions and from that point any attempt to deliver the foetus was useless. The next day I had to leave this interesting young woman, my

59 Lebrun 1995. 
soul racked by pain, and two days later she paid the highest price to nature, thanks to these bad counsellors. ${ }^{60}$

Benoite Cadeau-Fessel therefore found herself in an uncomfortable position. On one hand, she was confident in her knowledge and savoir-faire in obstetrics. Yet she found herself in a society unwilling to recognize her professional superiority to doctors. Despite her strong character she found herself subordinate to the medical profession. She faced a constant struggle to impose her professional authority.

\section{The hazards of imposing authority}

Despite these problems, Benoite Cadeau-Fessel's professional reputation grew both in Lima and gradually in the rest of Peru. The development of the printed press and the distribution of newspapers played an important role in her growing popularity. The families of women who had been assisted by her demonstrated their gratitude by publishing articles in newspapers, while Madame Fessel also wrote about cases she had treated. Limeñas of every social group learned about her knowledge, and increasingly called on her expertise. Doctors also called on her in cases of difficult and complicated labour. Benoite Cadeau-Fessel emphasized that she had been called a number of times to the hospital to operate on assisted deliveries in front of doctors.

With her popularity, came envy and suspicion from the medical profession. Undoubtedly her personality annoyed the doctors. Although her husband was the chief doctor of the maternity hospital, she knew more about obstetrics. Madame Fessel wrote publicly about the scientific details of situations in which she had intervened, whereas her husband, Dr Fessel, has only left writing in defence of his wife.

Benoite Cadeau-Fessel could therefore be described as having characteristics usually associated with men: she was audacious, sure of herself, proud of her occupation and did not consider herself to be professionally inferior to doctors. From an anthropological point of view, she was "active", a characteristic usually attributed to men. Perhaps her access to the profession of midwife had given her a

60 Cadeau-Fessel 1830b: IV-V. 
degree of freedom, enabling a type of self-affirmation previously denied to women. However in the highly conservative society of nineteenth-century Peru, her personality posed a problem for men, especially the doctors with whom she associated. Thus, despite her knowledge, Madame Fessel found herself subordinate to her doctors, even if they were less competent than her. This is shown in a very detailed description that she made of a highly complicated labour.

After having observed the patient, Doña Rosa González, Benoîte Cadeau-Fessel judged that the foetus was dead and it would be very difficult for it to emerge, given the narrow pelvis of the woman in labour. The doctors were called: five arrived, including her husband, Dr Fessel. They argued together, but could not agree on treatment. During this time Madame Fessel tried to minimize Doña Rosa's atrocious pain. Finally the doctors decided that it was necessary to drill into the foetus' skull so that the head could emerge. Because this was a surgical operation, the operation had to be done by a doctor. However the doctors shirked their duty. The patient's family appeared to question the necessity of the operation, which pushed the doctors to fear legal action. Dr Fessel then asked if they would sign a discharge paper so that Benoite Cadeau-Fessel could operate without the risk of later legal proceedings. She then found herself alone in front of the young woman in labour and proceeded to operate. ${ }^{61}$ This ended with Doña Rosa's death. In an entirely predictable way, Benoite Cadeau-Fessel then appeared to be the only person responsible for Doña Rosa's death. Dr Fessel organized his wife's legal defence, and in the end Dona Rosa's family did not start legal proceedings.

This example demonstrates how hard it was for Benoite CadeauFessel to create an air of authority around her, a problem of which she seems to have been aware. As someone who sought to uphold the important place of women in "humanity's most useful art" (and therefore to some extent in the polis), Cadeau-Fessel bitterly noted that it was very hard to fight against "the malicious gossip of people in Lima". ${ }^{62}$ Many people were wary of the type of power that

\footnotetext{
61 Cadeau-Fessel 1830b: 91.

62 Cadeau-Fessel 1830a: 23.
} 
midwives could wield and considered that there was no purpose in providing them with a maternity hospital and training school.

In 1827, the year after Madame Fessel's arrival in Peru, Lima's Cabildo (municipal council) created an inspection committee for its hospitals, a normal procedure. The committee's report severely criticized her, emphasizing that she "had the use of magnificent apartments with all possible comfort and a considerable annuity." 63 In reality, as Cadeau-Fessel herself noted, the inspection occurred before the promulgation of the decree that set the salary of the midwife. At the moment of the inspection, she was receiving no money from the state. Yet Benoite Cadeau-Fessel did not hesitate to spend 1,430 pesos of her own money to set up a clinic and send to France for the appropriate material for teaching obstetrics to her pupils. ${ }^{64}$

Despite these criticisms Benoîte Cadeau-Fessel's work had positive results. Ten years after her arrival in Peru, Lima's maternity hospital was still the only institution of its type in the whole of Latin America. Even if the budget was modest and the subsidies arrived late, the government backed the hospital in its project of fighting against "depopulation", a subject that worried a number of the new Latin American states.

The number of births in Lima's maternity hospital was still quite small, about a hundred a year but it regularly increased. The first graduating class of Peruvian midwives took the oath at the College of Medicine in 1833. Between this date and the end of the nineteenth century, over 200 young women graduated from there. And in turn the maternity hospital of Lima became a model in the Andean region. Two midwives trained by Madame Fessel established maternity hospitals inspired by the Limeño model, one in Quito (Ecuador) and one in La Paz (Bolivia).

Benoite Cadeau-Fessel was obliged to leave Peru in 1836 because of health problems. Yet she left something significant behind her. Her strong personality, her professional skills and her experience were increasingly acknowledged in Peru and neighbouring countries.

\footnotetext{
63 Cadeau-Fessel 1827b.

64 Cadeau-Fessel 1827b.
} 
By 1836, General Santa Cruz, president of Upper Peru, had heard of Madame Fessel's work in Lima. ${ }^{65}$ He took it upon himself to organize the recruitment of Juana Reyes, who had trained at the maternity hospital of Lima. Historians of Peruvian medicine - usually doctors themselves and therefore more interested in the role of doctors in history - have also devoted space in their works to the development of the Frenchwoman's work. Only two women in the nineteenth century have been so honoured: Benoite Cadeau-Fessel and Laura Rodríguez Dulanto, the first female doctor in Peru.

In conclusion, the Lima maternity mospital endured and became the most important obstetrics institute in Peru. Benoite CadeauFessel's legacy was also the creation of a new profession of certified midwives, who can be distinguished from their Spanish and United States counterparts. In the USA, midwives were rapidly subordinated to doctors, whereas Peruvian obstetrices managed to carve out an independent professional space. ${ }^{66}$ As Oliver Faure has noted for the French case, the history of Peruvian midwives demonstrates that not all certified midwives were brought to heel in the first half of the nineteenth century. ${ }^{67}$ Peruvian midwives used their profession to emancipate themselves and play a role in the polis, especially in suburban and rural regions. The importance of this can still be seen today in the Andean and Amazonian regions of Peru.

Translated by Heloise FINCH-BOYER

\footnotetext{
65 Costa Ardúz 2005: 528.

66 Quiroz-Pérez 2012.

67 Faure 2005.
} 


\section{Primary Sources}

Cadeau-Fessel, Benoîte Pauline. 1825. Consejos a las mujeres encinta. Guadalajara: D.M. Rodríguez Press.

- 1826. A las señoritas de la ciudad de Lima... Lima.

- 1827a. Curso elemental de partos. Lima: José M. Masías Press.

- 1827b. Reflexión sobre la organización de la Maternidad o Escuela de partos en Lima. Lima.

- 1830a. Noticia de una fecundidad extraordinaria y relación bistórica de una preñez. extrauterina. Lima: José M. Masías Press.

- 1830b. Práctica de partos u Observaciones hechas en cuarenta y cinco casos contra naturaleza y por vicio de conformación que se han presentado entre setecientas cuatro mugeres de parto asistidas en Lima en tres años y medio de práctica. Lima: J. Masías Press.

Carrasco, Eduardo. 1826. Calendario y guía de forasteros de Lima para el año de 1826. Lima: Impr. del Estado.

RaBi CHARA, Miguel. 2004. El Hospital de la Maternidad de Lima y la Escuela de Obstetrices del Perú (1826-1836). Lima: Grahuer Editions.

Roussel, Pierre. 1803. Le Système physique et moral de la femme. Paris.

\section{Bibliography}

Andreo GarcíA, Juan (ed.). 2002. Historia de las mujeres en América latina. Murcia: Universidad de Murcia.

BASADRE, Jorge. 1963. Historia de la República del Perú, vol. II. Lima: Peruamérica Editions.

Beauvalet-Boutouyrie, Scarlett. 1999. Naître à l'bôpital au XIXe siècle. Paris: Belin.

Cárdenas Castillo, Cristina. 2010. Europeos en el México decimonónico: redes, élites y educación. In XIV Encuentro de Latinoamericanistas Españoles: Congreso internacional 1810-2010: 200 años de Iberoamérica. Santiago de Compostela.

http://halshs.archives-ouvertes.fr/docs/00/53/05/72/PDF/AT8_Cardenas.pdf [accessed 11/10/14]

Carrillo Ana María. 1999. Nacimiento y muerte de una profesión. Las parteras tituladas en México. Dynamis 19: 67-190.

Costa Ardúz, Rolando. 2005. José Passamán, padre de la Medicina Legal en Bolivia. La Paz: Edobol. 
Diaz Robles, Laura Catalina and Luciano Oropeza SANDOval. 2007. Las parteras de Guadalajara (México) en el siglo XIX: el despojo de su arte. Dynamis 27: 237-261.

FAURE, Olivier. 2005. Les sages-femmes en France au XIX ${ }^{\mathrm{e}}$ siècle: les institutrices du système de santé? in Les Nouvelles pratiques de santé. Acteurs, objets, logiques sociales, XVIII XIXe siècle, ed. Patrice Bourdelais and Olivier Faure, 157-174. Paris: Belin.

GARrido GonZÁLEZ, Elisa (ed.). 1997. Historia de las mujeres en España. Madrid: Síntesis.

GÉLIS, Jacques. 1984. L'Arbre et le fruit. La Naissance dans l'Occident moderne (XVI $T^{e}$-XIX siècle). Paris: Fayard.

- 1988. La Sage-femme ou le médecin: une nouvelle conception de la vie. Paris: Fayard.

KnibieHLer, Yvonne. 1980. Histoire des mères du Moyen-Age à nos jours. Paris: Montalba.

- 2007. Accoucher. Femmes, sages-femmes et médecins depuis le milieu du XXe siècle. Rennes: ENSP Éditions.

LANNING, John Tate. 1985. The Royal Protomedicato: the regulation of the medical professions in the Spanish Empire. Durham: Duke University Press.

Lebrun, François. 1995 (2nd edition). Se Soigner autrefois: médecins, saints et sorciers aux XVII et XVIII siècles. Paris: Seuil.

Marland, Hilary (ed.). 1993. The Art of midwifery: early modern midwives in Europe. London, New York: Routledge.

Morales Suarez, Moisés. 2009. La atención médica del recién nacido en el Hospital de Maternidad e Infancia de México. Siglo xIx. In Revista Mexicana de Pediatría, 76(6): 271-277.

Morant Deusa, Isabel (ed.) 2005-2008. Historia de las mujeres en España y América Latina. Madrid: Cátedra. 4 vols.

NAri Marcela. 2004. Politicas de maternidad y maternalismo político: Buenos Aires, 1890 1940. Buenos Aires: Biblos.

OrTiz Gomez, Teresa. 1992. Luisa Rosado o el orgullo de ser matrona en la España ilustrada. Dynamis 12: 323-346.

Quiroz-PÉREZ, Lissell. 2012. De la comadrona a la obstetriz. Nacimiento y apogeo de la profesión de partera titulada. Dynamis 32/2: 415-437.

— 1996 L'Université de Lima à la fin du XVIII siècle. Unpublished master's thesis. Université de Paris I.

RATTNER GELBART, Nina. 1998. The King's midwife: a history and mystery of Madame du Coudray. Berkeley. Los Angeles, London: University of California Press.

Restrepo, Libia. 2006. Médicos y comadronas o el arte de los partos. La ginecología y la obstetricia en Antioquia, 1870-1930. Medellin: La Carreta Editions. 
ThÉBAud, Françoise. 2004. Les Mots de l'Histoire des femmes. Toulouse: Presses Universitaires du Mirail.

- (ed.). 2005. Special Edition on "Maternités". Clio HFS 21.

Walzer LEAvitT, Judith. 1986. Brought to Bed: childbearing in America, 1750-1950. New York, Oxford: Oxford University Press.

ZÁRATE María Soledad. 2007. De partera a matrona. Hacia la asistencia profesional del parto en Chile en siglo xix. Calidad en la educación 27: 284-297. 